\title{
TRANSFORMATION OF THE CHRISTIAN MODEL OF WORLDVIEW AS THE BACKGROUND OF AN ETHIC-AND-AESTHETIC CONCEPT OF J. GENET
}

\section{Semenets O. S.}

\section{INTRODUCTION}

The problematic scope of J. Genet autobiographical works is inextricably linked to his mentality of a fringe. Being in a liminal condition, the writer feels the need for self-identification. Deep solitude inherent in the inner state of the fringe forces J. Genet to seek ways of overcoming it in unity with God, aspiration for sanctity (G. Bataille, S. Isaiev, Yu. Mishima, J.-P. Sartre emphasized this fact, giving characteristics to the life and work of the writer). This aspiration also creates a range of problems which are common to the whole novelistic period of J. Genet's work: an appreciation of God and the nature of sanctity, and hence his understanding of morality-immorality, the identification of good and evil. In ethical-and-aesthetic terms, the writer consistently tries to, by shocking society, realize his own spontaneous need for self-determination, bring out his own formula of beauty and sanctity, organize and prove the validity of his views as an aesthetic system.

Being on the fringe of the moral society in the midst of the lowest strata of the population, deprived of the opportunity to identify himself in the dominant continuum, J. Genet loses the sense of verge, ceases to perceive Good and Evil, God and the Devil, morality and immorality in an appropriate way. According to the theory of Yu. Kristeva ${ }^{1}$, all this undermines self-identification, system and order and causes disgusting one. Joining the environment of traitors, scammers, "decent" criminals, shameless rapists, and murderers - all those whom the moral society treats with disgust, J. Genet dissolves in it. That is, we have a situation when "disgusting simultaneously builds and destroys the individual", which leads to self-aversion. The emergence of this feeling is justified by the Christianity as one of the virtues - humility before God (an example is St. Elizabeth). Disgusting can be identified with perversive because both do not refuse, but at the same time do not assume the implementation of prohibitions, rules and laws, and "using them and tearing them apart, do not recognize them". J. Genet being unable to change for himself the basic

${ }^{1}$ Кристева Ю. Отвращение / Юлия Кристева // Силы ужаса: эссе об отвращении / Юлия Кристева; [пер. с фр. А. Костикова]. - Х. : Ф-Пресс, ХЦГИ, 2003. - 256 с. - (Серия «Гендерные исследования»). 
constants of society, such as Religion, Morality and Law, undertakes writing activity in order to confirm their absurdity. He uses them and interprets them in his own way, perverts them. The writer, fascinated by the disgusting, imagines its logic, projects himself, introduces and, consequently, distorts the language both style and content. Thus, according to Yu. Kristeva, contemporary literature, represented by J. Genet, "transposes the dichotomous categories of Pure and Impure, Prohibition and Sin, Morality and Immorality”2.

\section{The path to "sanctity" by Jean Jenet}

Reinterpretation of the conventional and instilled in early childhood religious and moral virtues occurs for $\mathrm{J}$. Genet in the process of his marginalization. Once he finds himself under classed where religion and morality are neglected, J. Genet begins to adapt his knowledge to the environment. That is why we agree with S. Isaiev ${ }^{3}$, who believes that praising and glorification of murder, betrayal and violence as the highest virtues masks the Christian model of worldview of J. Genet. Indeed, the writer's prose works are oversaturated with Christian symbols, images, motives, plots, but their understanding is somewhat different from the universal Christian vision.

The writer, being left by a twist of a fate outside of society, transposes the idea of faith into a marginal space, rejecting conventional understanding of religion. Thus, J. Genet repeatedly emphasizes that he goes to seek not just God, but his own God through the attainment of sanctity, but in the sense that he himself put into this word, considering "la saintete" the most beautiful word in French language. His God was the god of criminals and murderers, that's why he projects the divine sphere into a criminal world, creating his own religion based on unity and identity to God.

Rejection of Christian tenets by a future writer goes back to his childhood. Children in orphanages, where J. Genet was brought up, were raised in a rather harsh environment, but religion as the only way to save the soul was imperative in this process. That is why faith in God, instilled from a young age, has been with the writer throughout his life. However, narrow-mindedness of priests who hid themselves under the commandments of God and chose not to notice the heyday of the outrage and dirt that prevailed in the penitentiary facilities and orphanages forever turned J. Genet away from the church. Hence the disdain for its representatives observed under any references to the ministers of the church in the novels of the writer. A striking illustration is the childhood

${ }^{2}$ Кристева Ю. Отвращение / Юлия Кристева // Силы ужаса: эссе об отвращении / Юлия Кристева; [пер. с фр. А. Костикова]. - Х.: Ф-Пресс, ХЦГИ, 2003. - 256 с. - (Серия «Гендерные исследования»). - С. 52.

${ }^{3}$ Исаев С. Нежный / С. Исаев // Строгий надзор / Жан Жене; [Сост. С. Исаев]. - М. : Изд-во «ГИТИС», 2000. - С. 7-22. 
episode in the novel "Miracle de la rose", which took place during the visit of the bishop from Tours to the Mettray Penal Colony. The director of the colony pathetically welcome the bishop and expressed confidence that from now because of the presence of the holy father of the church "Les colons ne prennent la résolution de vivre saintement" ${ }^{4}$, and all of a sudden when exchanging mutual courtesy in "cette oasis d'un calme religieux" ${ }^{5}$ " "cette colonie est une pépinière d'hommes gagnés à Dieu”, , between Rigo and Ray through some former quarrel began a real fight to death "jusqu'à la damnation"” ${ }^{7}$, which clearly testified to the vanity of sermons and blessings. In general, the hypocrisy of church officials was a constant pretext for the irony of J. Genet, who portrayed them in a very unattractive way. One of the priests buys for money the love of a young homosexual and for love promises him the position of church warden in his parish, another one has a love affair with a logger on a meadow, the third one sneaks to the altar, the fourth one with disgust gives an oblation for the Holy Communion to the souteneur Mignon and prostitutetransvestite Divine. The nuns are also not a model of repentance and humility. In "Miracle de la rose", the Sister Superior does not even try to understand the colonist, but rather " $<\ldots$..> le regardait avec, sur ses lèvres, ce qu'elle appelait son sourire de miséricorde”, , calls him a hypocrite. Another Sister of Mercy from "Miracle de la rose" hates juvenile criminals and tries to inject them as painfully as possible.

Gradually, J. Genet begins to doubt the basic tenets of religion, and finds Christian dogma imperfect. Thus, he thinks: “ $<\ldots$..> car du sacré, qu’on appelle, hélas! Le spirituel, on ne rit ni ne sourit: il est triste. S'il est ce qui touché à Dieu, Dieu est donc triste? Dieu est donc une idée douloureuse? Dieu est donc mal? <..>"' . But no, after all "Dieu est bon, c'est-à-dire qu'il sème tant d'embûches sur notre parcours que vous ne pouvez pas aller où il vous mène" 10 . Realizing that a human is tainted since their birth because of the original sin, and therefore can not change anything, yet they dare to live and live to the full, J. Genet is ready to name it "la beauté des grandes malédictions, car c'est digne de ce que fit dans le cours de tous les âges l'Humanité mise à la porte du Ciel. Et c’est proprement la sainteté, qui est de vivre selon le Ciel, malgré Dieu”"11.

${ }^{4}$ Genet J. Miracle de la rose // Oeuvres completes de Jean Genet. II. Paris, Gallimard, 1952. P. 160.

${ }^{5}$ Ibid. P. 161.

${ }^{6}$ Ibid. P. 161.

${ }^{7}$ Ibid. P. 162.

${ }^{8}$ Ibid. P. 239.

${ }^{9}$ Genet J. Notre-Dame des Fleurs. Lyon: Barbezat-L'Arbalète, 1948. P. 139.

${ }^{10}$ Genet J. Miracle de la rose // Oeuvres completes de Jean Genet. II. Paris, Gallimard, 1952. P. 288

${ }^{11}$ Ibid. P. 45. 
That is, sanctity leads to Heaven through crime, and "Les voies de la sainteté sont étroites, c'est-à-dire qu'il est impossible de les éviter et, lorsque, par malheur, on s'y est engagé, de s'y retourner pour revenir en arrière" ${ }^{12}$. This refers us to the assertion about the path of the criminal (once committing a faux pas, having committed the crime, it is impossible to correct anything and become pious. One should go all the way).

Constantly speaking ironically about Christian religion and blind faith in the tenets of the church, J. Genet tries to "defecate" from any religiosity. But, according to M. Eliade, the modern religious human, try as they would to free themselves and get rid of the prejudices of their ancestors, still remains the heir of a religious human. That is why, since they deny religion, and reject it, but "conceals in the depths of their nature a religiously oriented behavior" ${ }^{3}$. J. Genet, experiencing an existential crisis, finds salvation in building his own system of values, a kind of "own religion" that is adapted and transformed to his own needs by a Christian model of worldview.

J. Genet chooses his path to God through the attainment of absolute sanctity, and in order to become saint one must "as a coat, take off the Christian morality". And above all, in order to understand the writer and support his point of view, one must get rid of Christianity stereotypes. That is why the author constantly tries to shock the reader with candid characters which appeal to the biblical. Thus, to the prostitute-transvestites he gives the names of First Communion, Paradise Apple, Teresa. He does not aim at making fun of the Christian religion, he really wants to impart chastity and purity to his characters, trying to rehabilitate them in the eyes of the community. J. Genet notes " $<\ldots$. > ses noms sont venus au hasard. Il existe entre eux une parenté, une odeur d'encens et de cierge qui fond, et j'ai quelquefois l'impression de les avoir recueillis parmi les fleurs artificielles ou naturelles dans la chapelle de la Vierge Marie, au mois de mai $<\ldots>$ " 14 . The author gives the name of Our Lady (Notre Dame) to the cold-blooded killer. The life of the writer's heroes is "le Ciel souterrain" ("the underground sky"), where bartenders, pimps, homosexuals, and night beauties reside, but their life is Heaven. Projecting the world of the sacred to the criminal environment, J. Genet calls the young colonists who are capable of betraying their comrades and being sold to the guards, as angels or children of angels, the killer of Gorgi - as the Archangel. Jesus' commandment of "Love!" he interprets as such, which " $<\ldots>$ devait donner naissance au plus

${ }^{12}$ Genet J. Miracle de la rose // Oeuvres completes de Jean Genet. II. Paris, Gallimard, 1952. Р. 265.

${ }^{13}$ Еліаде М. Священне і мирське; Міфи, сновидіння і містерії; Мефістофель і Андрогін; Окультизм, ворожбитство та культурні уподобання / [пер. Г. Кьоран, В. Сахно]. К.: Видавництво Соломії Павличко «Основи», 2001. С. 112.

${ }^{14}$ Genet J. Notre-Dame des Fleurs. Lyon: Barbezat-L'Arbalète, 1948. P. 340. 


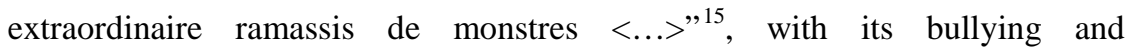
reincarnations for the sake of carnal, filthy love. Describing the way of life of the colonists who lived in homosexual families in Mettray Penal Colony, J. Genet appeals to the Bible: “ $<\ldots$..> le livre d'Enoch: "Les anges se choisirent chacun une femme, et ils s'en approchèrent. Et ces femmes conçurent. Et elles enfantèrent des géants dont la taille... Ils dévoraient tout ce que les hommes pouvaient produire. Les anges aux enfants enseignaient la magie, l'art de faire des épées et des couteaux, des boucliers, des cuirasses et des miroirs $<\ldots>-$ de sorte que le monde fut corrompu, l'impiété s'accentua et la fornication se multiplia”. Ces textes m'étant tombés sous les yeux, il me parut que l'on ne pouvait peindre ou dépeindre mieux le domaine secret des colons $<\ldots$.."16. The word "amen" for the writer is in tune with the word "a frenching?" or "ammonia", and the male genital organ is similar to the Infant Jesus resting in a crib. The biblical story of washing of Jesus' feet J. Genet brings into the space of the chamber of the Fontevrault prison, where the renegades of the lower rank wash feet to the leaders. For the writer's heroes plundering the church for the sake of making money is not a sin, but a common thing.

Such an overloading of novels with transformed Christian metaphors is intended to expand the limits of the conventional understanding of sanctity, because the lowest heroes of the novels are closest to God. It is symbolic for the writer that modern prisons are housed in the former buildings of temples and churches, so prisoners and colonists are often compared to monks. In addition, they renounce all earthly goods, as the Church enjoins. Being the most abhorrent of creatures, the representatives of the social bottom constantly feel the oppression of condemnation and neglect of the dominant continuum, that is, they already atone for their sin. At the same time, Jean, Divine, Querelle and others deliberately renounce everything they love and cherish, as they approach to sanctity, they become lonely and suffer from it. By the law of God, they deserve more to be forgiven because their atonement is conscious and thorny. And forgiveness leads to sanctity, in Heaven, draws closer to God.

J. Genet warns the reader not to equate the generally accepted interpretation of the concept of "sanctity" with his own, because for him it has a completely different meaning; it is an authority that is beyond the concepts of Good and Evil. The writer gives a form of mystery, a sacred ritual to the life of his characters, just to remind people, " $<\ldots>$ that higher reality, sacred, divinity goes beyond their mental perception that Grund can only be grasped as a mystery and paradox, that divine perfection must not be perceived as the sum of

${ }^{15}$ Genet J. Miracle de la rose // Oeuvres completes de Jean Genet. II. Paris, Gallimard, 1952. P. 238.

${ }^{16}$ Ibid. P. 148. 
qualities and virtues, but as absolute freedom, beyond good and evil <... ${ }^{17}$. For J. Genet, in order to comprehend God and the higher reality, one must refuse " $<\ldots>$ to feel divine in the concepts of direct experience $<\ldots$.. ". To attain sanctity for the writer's heroes means to completely surrender to evil, to succeed in such a moral act that is beyond the concept of "morality", to act beyond good and evil, to commit crime for crime, evil for evil, and therefore for good ("Je suis emporté dans cette chute qui. coupant par sa vitesse même et sa verticalité tous les fils qui me retiennent au monde, m'enfonce dans la prison, dans l'immonde, dans le rêve et l'enfer pour atterrir enfin dans un jardin de sainteté où fleurissent des roses $<\ldots{ }^{\text {"18 }}$ ).

And the more serious crimes are committed by the killer, knowing that with every crime he moves farther and farther away from everything on earth, the closer he is to God. Sanctity for J. Genet is "unity with God", and consequently identity with God. Based on the unity of the Father, the Son, and the Holy Spirit, J. Genet proclaims that anyone who attains sanctity can be equated with God. Hence he identifies dishonest killers with the Holy Spirit, Jesus and God.

\section{2. "Notre-Dame-Des-Fleurs" as the first step of the writer's ethico-aesthetic concept}

The first novel "Notre-Dame-Des-Fleurs" J.-P. Sartre described as a "peak of discontent", in which J. Genet seemed to be trying to break free from "poisoning" by traditional morality and to approach sanctity by way of the utmost exaltation of crime, prostitution and violent death. The purpose of human downfall for J. Genet is ritual purification. At the beginning of the work, the death of the protagonist, Lou Coulafrois, a prostitute-transvestite nicknamed Divine (Godly), and the events after his death have been already depicted. The novel ends with depiction of the last moments of the hero's life. J. Genet builds the plot of the novel so that Divine's life and death become the background for the destiny of other characters. All of them, when being at the bottom of society, rise to the top only because they accidentally come across the living space of the "heroine". First it is a pimp Mignon, then a young killer, a petty drug-slut Notre Dame de Fleur (Our Lady of the Flowers), then a darkskinned criminal Gorgi and others.

In general, the novel "Notre-Dame-Des-Fleurs" is based on the biblical story of Jesus actions. Before Notre Dame, Mignon emerges in the novel, who

17 Еліаде М. Священне і мирське; Міфи, сновидіння і містерії; Мефістофель і Андрогін; Окультизм, ворожбитство та культурні уподобання / [пер. Г. Кьоран, В. Сахно]. К.: Видавництво Соломії Павличко «Основи», 2001. С. 362.

${ }^{18}$ Genet J. Miracle de la rose // Oeuvres completes de Jean Genet. II. Paris, Gallimard, 1952. P. 202. 
is initially mistakenly compared to the infant Jesus. It is then reported that “Ondoyé, c’est-à-dire béatifié aussi, canonize quasi, fut Mignon, avant sa naissance, dans le ventre chaud de sa mère. On lui fit cette sorte de baptême blanc qui devait, dès que mort, l'envoyer dans les limbes $<\ldots{ }^{\text {"19 }}$. Likewise, John the Baptist, the forerunner of Jesus, was often confused with the Messiah because of his special status. Mignon was called to bring into the world Notre Dame, to inform people about him. He will never become God himself, for he is not capable of indulging in evil and crime as selflessly as Notre Dame, who, according to Divine, was the "innocent killer" who similar to Jesus appeared sinless before the Father of God. Like Jesus, who was unable to retreat from the Holy Prophecy, though it caused terrible torment, Notre Dame knows that “ $<\ldots>$ son destin s'accomplit et, s'il sait $(<\ldots>)$ que son destin s'accomplit à chaque instant $<\ldots>{ }^{20}$ and so he undergoes a kind of "bloody baptism" which gives him the right to be called Notre Dame, that is, the Virgin Mary. Then the activities of Notre Dame begin. Crime by crime, betrayal by betrayal, and he closer approaches God, however “ $<\ldots$..> ne pensait à rien, et c'est ce qui lui donnait l'air de tout savoir d'emblée, comme par une sorte de grâce. Etait-il le favori du Créateur? Dieu l'avait peut-être mis au courant. $(<\ldots>)$; mais, puisque les littérateurs expliquent que les yeux des petits Jésus sont tristes jusqu'à la mort de la prévision de la Passion du Christ, j'ai bien le droit de vous prier de voir, dans le fond des prunelles de Notre-Dame, l'image microscopique, invisible à votre oeil nu, d'une guillotine" ${ }^{21}$. So, as Jesus knew that for his glorious deeds he would be crucified on the Cross to resurrect and be reunited with his Father, so Notre Dame consciously committed the murders, knowing that they would bring him glory and bring him to the scaffold and his death will be the last stage of sanctification, as "La mort de Bulkaen et de Botchako auraient dû les édifier, les sanctifier $<\ldots$..”22 There are 12 jurors present at the hearing of the Notre Dame case, like 12 apostles of Jesus. The chairman of the hearings is a kind of embodiment of Pontius Pilate, who believes in the divine nature of the killer and does not want to execute him, so he repeatedly asks the young man not to confess. And as Jesus says in court, "I am the Son of God", so does Notre Dame shout: "Je suis l'Immaculée Conception"23. And before execution "Les gardiens lui parlèrent et le servirent, comme si, le sachant chargé du poids des péchés du monde, ils eussent voulu attirer sur eux la bénédiction du Rédempteur" ${ }^{24}$. Thus, the court became his God, and the

\footnotetext{
${ }^{19}$ Genet J. Notre-Dame des Fleurs. Lyon: Barbezat-L'Arbalète, 1948. P. 50.

${ }^{20}$ Ibid. P. 104.

${ }^{21}$ Ibid. P. 267-268.

${ }^{22}$ Ibid. P. 248.

${ }^{23}$ Ibid. P. 323.

${ }^{24}$ Ibid. P. 353.
} 
sentence was his resurrection, for he attained the highest sanctity, having confessed his sins and received the death sentence (decapitation). By the way, J. Genet chooses this kind of death sentence for all his heroes whom he magnifies to the saints, through his own steady " $<\ldots>$ aspiration vers une sainteté aux éclats assourdis $<\ldots>$ " 25 , and that is what encourages him to " $<\ldots$. firent secrètement élire la décapitation qui a pour elle d'être réprouvée, de réprouver la mort qu'elle donne, et d'éclairer son bénéficiaire d'une gloire $<\ldots>$ " 26 . If we turn to the research of M. Eliade, the decapitation can be interpreted in different way. The human's body is a temple in which the soul lives, and their head is the closest to the sky, through the upper hole the soul flies up to the sky at the moment of death. Dead yogis are usually punched in the skull to help the soul leave the body $<\ldots>$. ${ }^{27}$.. In the novel by J. Genet, the decapitation also symbolically facilitates and accelerates the way of the condemned saint to complete reunion with God.

All the characters of the novel aspire to the divine essence. Lou Coulafrois, a prostitute-transvestite, chooses the name Divine, which means "Godly", and on the way to sanctity plays the role of a martyr. Devine is devoutly pious; she goes to the church every Sunday, enduring the disdain of people around her and aversion of the priest. She, like Coulafrois, will always be compelled to " $<\ldots>$ d'aimer ce qu'elle abhorre, et cela constitue un peu de leur sainteté, car c'est du renoncement" ${ }^{28}$. She is hated by her own mother and despised by her lovers, her friends constantly betray her, and loneliness becomes her an eternal companion, but for the sake of sanctity, Divine compels herself to love them all even more and " $<\ldots>$ fait de ses amours un dieu audessus de Dieu, de Jésus et de la Sainte Vierge $<\ldots>$ " ${ }^{29}$. To be immoral requires a great deal of effort, which causes her suffering. For Divine to commit a crime for the sake of breaking free from the pressure of morality means only to be even closely connected with it. As if the Prophet Divine is walking around the streets of the city and singing Veni Creator. She often thinks of a suicide as a way to sanctity, but she does not dare to commit it and decides to kill an innocent girl and receive the death penalty for this crime. Thus, surrendering to police after committing a crime "Elle ne vivra plus que pour se hâter vers la Mort”, ${ }^{30}$, to her own sanctity, for she already knows that she is saint, because

${ }^{25}$ Genet J. Miracle de la rose // Oeuvres completes de Jean Genet. II. Paris, Gallimard, 1952. P. 7.

${ }^{26}$ Ibid. P. 7.

${ }^{27}$ Еліаде М. Священне і мирське; Міфи, сновидіння і містерії; Мефістофель і Андрогін; Окультизм, ворожбитство та культурні уподобання / [пер. Г. Кьоран, В. Сахно]. К.: Видавництво Соломії Павличко «Основи», 2001. С. 92.

${ }^{28}$ Genet J. Notre-Dame des Fleurs. Lyon: Barbezat-L'Arbalète, 1948. P. 164.

${ }^{29}$ Ibid. P. 142.

${ }^{30}$ Ibid. P. 359. 
“ $<\ldots>$ la sainteté fut sa vue de Dieu et, plus haut encore, son union avec Lui.

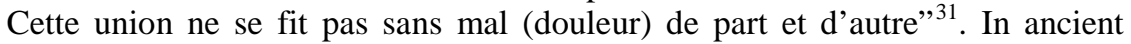
cultures, physical and mental sufferings were equated with the torture required for initiation, and therefore revival. Devine deliberately condemns herself to such suffering, and the girl's "ritual killing" is the final stage of consecration, the penultimate stage in the final reunion with God.

God is also Clement, to whom after the murder of his lover the light came down from heaven and made him " $<\ldots$.. prêtre. sacrificateur. officiant" ${ }^{32}$, who " $<\ldots>$ avait ordonné, vengé, sacrifié, offert, il n'avait pas tué $<\ldots>$ ”33. In his studies as to the mystical light, M.Eliade concludes that "meeting with light $<\ldots>$ radically changes human life, opens the world of the spirit" ${ }^{34}$. Thus, "having closed his eyes to his common sense", Clement broke free from his Christian soul, as if from pagan rags, and understood his mission in the world.

If in "Notre-Dame des Fleurs" biblical figures are used in a chaotic way, and the author sometimes contradicts himself, indicating that the author's vision of the problem has not been completely formed, then in the following prose work there is a clearly expressed hierarchy of saints, as well as specific and only accessible path to God in the perception of J. Genet is outlined.

\section{Worldview constants in the novels "Miracle de la Rose" and "Pompes funèbres"}

In the novel "Miracle de la Rose", the features of Jesus and God are given to the prisoner of Fontevrault prison Harcamone, who is sentenced to death because of double homicide. Every time Harcamone is mentioned there is a reference to the light that was radiated by him. In India and many other countries, the light is identical with being and immortality, and in M. Eliade's opinion, "light is the very essence of the divinity, and the mystically perfect beings are radiant” ${ }^{35}$. Thus, appealing to our religious subconscious, J. Genet tries to make the reader also believe in divine nature of this criminal. The criminals sought to get to the Central to be closer to Harcamone, as the pilgrims flocked from everywhere to the sacred place (Fontevrault prison is repeatedly compared to the Church) to pay homage to God. For Jean, the main character of the novel, Harcamone is the embodiment of Christ, who deliberately chose for himself the destiny of the redeemer and forever destroyed

\footnotetext{
${ }^{31}$ Genet J. Notre-Dame des Fleurs. Lyon: Barbezat-L'Arbalète, 1948. P. 361.

${ }^{32}$ Ibid. P. 188.

${ }^{33}$ Ibid.

${ }^{34}$ Еліаде М. Священне і мирськ ; Міфи, сновидіння і містерії; Мефістофель і Андрогін; Окультизм, ворожбитство та культурні уподобання / [пер. Г. Кьоран, В. Сахно]. К.: Видавництво Соломії Павличко «Основи», 2001. С. 312.

${ }^{35}$ Ibid. C. 321.
} 
all the ways to salvation and earthly life, when he deliberately killed the overseer. "Harcamone "m'apparaissait", 36 , - Jean remembers seeing a doomed prisoner on a walk. He continues: "Je sentais, dans toutes mes veines, que le miracle était en marche. Mais la ferveur de notre admiration avec la charge de sainteté qui pesait sur la chaîne serrant ses poignets - ses cheveux ayant eu le temps de pousser, leurs boucles s'embrouillaient sur son front avec la cruauté savante des torsades de la couronne d'épines - firent cette chaîne se transformer sous nos yeux à peine surpris" 37 . Harcamone was already the Son of God, because after committing the murder, he achieved " $<\ldots>$ la pureté gagnée par le sang - on dit le baptême du sang <...>"38, he had walked his short path of sanctity and was then awaiting the death penalty to take the final step to reunion with God, to be sanctified. A violent death on the scaffold would give him the glory of a "superhuman", because after the death, the head of the dead is crowned with a nimbus, like that of the holy martyrs. When the overseers were beating him, Harcamone heard God speaking to him: "Tu seras roi, mais la couronne qui te serrera la tête sera de fer rougi $<\ldots>$ ". 39 . This is exactly how the King of all people was crowned with a crown of thorns. Harcamone, like Notre Dame from "Notre-Dame des Fleurs", was also a lamb for sacrifice, a sacrificial offering.

Jean became a symbolic Pupil of Christ-Harcamone. He suffered with him, tried to give his life powers to the Master, and through this he received a vision that indicated the right path to sanctity, to God: "Ce meurtre d'une enfant par un enfant de seize ans devait m'amener à cette nuit où me serait donné la vision d'une montée vers le paradis qui m'est offert <..." 40 . Jean sought sanctity, and Harcamone pointed him his way. In this novel, the process of attaining sanctity is less important to the writer then miraculous power of the sacred influence that Harcamone exerts on others. And in order for the reader to finally "believe", the narrator describes the miracle of the killer's resurrection. The executioner and the guards found a mysterious red rose in Harcamone's heart, " $<\ldots>$ monstrueuse de taille et de beauté" ${ }^{41}$, and were stunned by its grandeur, because "Les rayons de la rose les éblouirent $<\ldots$. " 42 . However, the executioners who don't "believe" are unable to feel respect and reverence to the miracle of resurrection. The red rose has long been the epitome of the mercy and torments of Christ, for it grew from the drops of His blood on Golgotha.

${ }^{36}$ Genet J. Miracle de la rose // Oeuvres completes de Jean Genet. II. Paris, Gallimard, 1952. P. 18.

\footnotetext{
${ }^{37}$ Ibid. P. 18-19.

${ }^{38}$ Ibid. P. 95.

${ }^{39}$ Ibid. P. 229.

${ }^{40}$ Ibid. P. 278.

${ }^{41}$ Ibid. P. 285.

${ }^{42}$ Ibid. P. 285.
} 
By using the symbol of the rose to portray the resurrection of Harcamone, J. Genet enhances the effect because the rose is the ancient symbol of God in many mythologies and religions. It is simultaneously a symbol of the Passions of Christ, and eternal life, and resurrection, and martyrdom, and the emblem of the saints, and the sign of the sacrament.

If in "Notre-Dame des Fleurs" the narrator only tries to find the way to God, to define for himself the notion of sanctity, and therefore gives divine names to many heroes, main and minor, then in "Miracle de la Rose" there is already the one God - Harcamone, and all others only the angels and His pupils, and Harcamone's path to sanctity is the only right one.

In the same plane as the nature of sanctity, there is a solution to other problems which lead to it. And above all, it is a problem of betrayal, as a moral act, which gets a human closer to sanctity. The third novel by J. Genet ("Pompes funèbres") is dedicated to the mentioned problem. According to P. Bugon, this is "the first work of J. Genet, in which the fixation of politics and history is essential" ${ }^{43}$. The events of the novel unfold on the background of World War II, the fights for Paris liberation, the period of German occupation, when each person made their choice which side to take. The problem of betrayal is not new to J. Genet's work, however, if in "Notre-Dame des Fleurs" and "Miracle de la Rose" it is less important, and the author mentions it only as an attribute of sanctity and only in certain episodes, then in "Pompes funèbres" it becomes fundamental. The path to sanctity has already been outlined in previous works, and J. Genet, in addition to murder, includes to the saint virtues also the virtue of betrayal.

The novel is full of biblical symbols, characters, Holy Scripture quotes, and prayers. The interpretation of the commandment of God, which says "Love thy neighbor!", is supplemented by J. Genet in the key to the concept of sanctity. Christians love more when they suffer, and suffering leads to martyrdom and sanctity. The narrator is the main character, brings the police to his friend's from the Resistance movement, reflects: "Sans doute cette trahison me cause une souffrance inouïe, m'apprenant de même coup mon amitié pour ma victime et pour l'homme un amour encore vivace, mais au milieu de cette souffrance, il me semblait que demeurât, la honte m'ayant brûlé de toute part, au milieu des flammes ou plutôt des vapeurs de la honte, d'une forme aux lignes sévères et nettes, d'une matière inattaquable" ${ }^{44}$. One should be very mean spirited to betray and kill those you love, but betrayal and killing are a kind of sacrifice for the glory of God, because they lead to loneliness and renunciation of all that is dear to the heart. The novel is imbued with the cult of betrayal: the

${ }^{43}$ Bougon P. Politique, ironie et mythe dans Pompes funèbres // Europe. août-septembre 1996. №808-809. Р. 66.

${ }^{44}$ Genet J. Pompes Funèbres. Paris, Gallimard, 1953. P. 82. 
mother of the fallen resistance activist Jean has a lover - a Nazi Eric, her maid for money has love affairs with German soldiers and betrays them to her boyfriend, who is fighting on the side of the French, the narrator is a lover of Eric, although he is acquainted with the mother of his beloved deceased Jean, Rhyton does not even know who sell himself out to move to abyss faster. He joins the Militia forces, the vilest dregs that punish their fellow citizens, makes love to Eric, and then kills "freak" out of love for him. The apostasy of this feast of betrayal becomes the priest's delation on the rebels. Rhyton motivates his act by the idea that "Il fallait à Dieu cet admirable péché" 45 i "Dieu se révèle à moi qui révèle le péché des autres" ${ }^{46}$. And all of this is done by the heroes of "Pompes funèbres" through love, for even the priest calls, "Save them!”. Great love, concentrated in betrayal as a liminal manifestation, brings the feeling of total loneliness that comes when you betray or find yourself betrayed.

The problem of solitude, which is one of the fundamental for existentialism, which representative J. Genet was to some extent in his early works, is also resolved by the writer in the context of sanctity. Solitude for him is an achievement on the way to sanctity. It is sacred because it brings torments. Hermit monks immured themselves in cells or went to the deserts, where alone and in poverty, devoid of all earthly temptations, learned revelation, got closer to God. From the very beginning, the representatives of the social underclass had nothing to tempt them in the Christian sense of the term - neither wealth nor power, so to achieve sanctity they only needed to attain solitude, so that nothing could distract them from their goal to become "the saints". And such unbearable solitude the fringes obtained through the betrayal of loved ones.

The problem of solitude is closely connected with the problem of freedom, in the sense of freedom of choice and universal freedom from all the earthly, which is equal to sanctity. According to Yu. Pokalchuk "in his ecstatic, almost religious praising of absolute freedom of the human person, free to do both good and evil, there is indeed something that fascinates, compels even involuntary to listen to him as to inexplicable, but obviously complicated and energetic prayer of the Tibetan monk" ${ }^{47}$. Even Jesus was free from the Christian morality distorted by the Jews (for example, He healed on Sabbath - the holy day of rest, defended the woman-sinner who had committed the terrible sin of adultery). The Son of God himself chose his way of redemption, knowing about the Passion of the Christ. For J. Genet, sanctity is equal to freedom.

${ }^{45}$ Genet J. Pompes Funèbres. Paris, Gallimard, 1953. P. 248.

${ }^{46}$ Ibid. P. 248.

${ }^{47}$ Покальчук Ю. Дзеркальні лабіринти «святого» Жене // Покоївки: [П’єса] / [пер. із фр. та післямова Ю. Покальчука]. Львів: Кальварія, 2002. С. 120. 
The problem of solitude in the "Haute surveillance" is also dominant, as solitude is a sign of freedom and therefore sanctity for the Green-eyed man. "Je suis tout seul $<\ldots>$ " 48 , "Maintenant je suis tout seul"49, "Je suis la forteresse et je suis seul au monde" ${ }^{50}$ - he constantly exclaims. However, if in the novels solitude was a conscious choice of the main characters on the way to sanctity, then the Green-eyed man does not dare to terminate his relationship with his wife, he wants someone to bring flowers to his grave and mourn for him after his execution ("YEUX-VERTS: “< ..>. Elle pourrait venir prier sur ma tombe et y porte... (Il hésite.) des fleurs..."51. Lefrand seeks to make the Green-eyed man completely free, so he deliberately causes a quarrel between him and his wife, considering her a burden for his idol: "LEFRANC: Oui, mon petit Maurice, tu as deviné: depuis longtemps je fais mon possible pour qu'elle le laisse choir. <...>. Il y a longtemps que je cherche à le décoller d'elle. Je m'en fous de sa femme. D'elle je m'en fous. Je voulais que Yeux-Verts soit tout seul" ${ }^{52}$. The Green-eyed man finally realizes that on the way to sanctity, he must give up everything on earth, and his wife as well, and in order to make his fall even more abrupt, to kill her. But he is imprisoned, so the only possible way out is a renunciation, a symbolic act of killing their feelings: "YEUX-VERTS: "Va lui dire qu'elle s'en retourne". LE SURVEILLANT: "Définitif?" YEUXVERTS: “Tout ce qu'il y a de. Mademoiselle est morte" ${ }^{53}$.

\section{4. "Evil for the sake of Evil" in the novels "Querelle de Brest" and "Journal du voleur"}

The writer further deepens the meaning of the concept of sanctity, thoroughly revealing it mostly in his fourth novel "Querelle de Brest". The key point of the question has already been raised in the novel "Miracle de la Rose" and in the play "Haute surveillance", which thematically and problematically are more related to the prose work of the writer than to the playwriting. To become a completely free from social, moral and religious rules, a judge and a defendant at the same time, the master of his destiny, life and death, doing both good and evil freely, and therefore, beyond these concepts, Harcamone and Green-eyed man have committed their horrific crimes, and that gave them a resurrection and a divine essence. Jean, a character from "Journal du voleur" took his friend's money and gave it to the street beggars. While his abducted friend was starving to death in the ditch,

\footnotetext{
${ }^{48}$ Genet J. Haute surveillance : (Nouvelle version). Paris : Gallimard, 1993. P. 50.

${ }^{49}$ Ibid. P. 49.

${ }^{50}$ Ibid. P. 71

${ }^{51}$ Ibid. P. 45.

${ }^{52}$ Ibid. P. 37-38.

${ }^{53}$ Ibid. P. 73.
} 
the protagonist considered himself "liberated from the moral troubles" due to this crime. The traitor, police officer Mario, sees freedom in the possession of someone else's life, so he postpones the solution of the question to kill or not to prolong and enjoy this sweet moment of absolute freedom. In "Querelle de Brest", the author goes on, and the protagonist, devoting himself to evil for the sake of evil, knew that he would be saved by God ${ }^{54}$, as an absolute evil is the good and "Comme le bien, le mal se gagne peu à peu par une découverte géniale qui vous fait glisser verticalement loin des hommes $<\ldots>$ " 55 . He is completely sinful, he has nothing more to lose, so he can do whatever he wants, and therefore is completely free. On his way to freedom-sanctity, he dares to commit not only a betrayal, but betrayal of his beloved Disciple, another God, in the gaze and smile of whom the day before " $<\ldots>$ se distinguaient déjà la tristesse et le désespoir de la Crucifixion” 56 . Despite his love for Gilles, Querelle betrays him as he has betrayed his brother, having slept with his mistress, Madam Liziana, and then with her husband, and telling everyone about this, embarrassing Robert to make his last sacrifice and become lonesome in his greatness. So God offered his Son for the atonement of human sins. Lonesome as well is Divine from "Notre-Dame des fleurs", who feels superfluous in the union of Gorgi and Notre Dame, and therefore suffers and seeks to exacerbate this suffering, ultimately severing his relationship with the world by committing suicide. The feeling of solitude does not leave the Green-eyed man from "Haute surveillance", but his loneliness is a reward, freedom, chosenness. Jean remains alone in the world, the protagonist of "Miracle de la Rose" and "Journal du voleur". However, they do not aspire to their solitude; it is a punishment, a sensation being gained in the first years after their birth, and carried through the whole life. The pervasive motive of universal solitude, which is presented in all works by J. Genet, has provided the grounds to R. Ko to declare him "le poète de la solitude" ("poet of solitude"). Solving the problem of solitude as a punishment and as a consciously chosen path can be explained by the personal marginality of the writer, whose worldview is also split due to the ambiguity of his self-awareness.

In the latest novel by J. Genet "Journal du voleur" which is the original result of the development of his philosophical-and-aesthetic concept and his own Book of Genesis, the commandments of which he must follow, the writer finally determines the concept of sanctity for himself as renunciation, and therefore freedom. Having passed a long way in defining his own life

\footnotetext{
${ }^{54}$ Genet J. Querelle de Brest. Paris, Gallimard, 1953. P. 331.

${ }^{55}$ Genet J. Pompes Funèbres. Paris, Gallimard, 1953. P. 81.

${ }^{56}$ Genet J. Querelle de Brest. Paris, Gallimard, 1953. P. 225.
} 
position, in developing his views and beliefs, the writer returns to the archaic perception of the sacred as a concept that lies beyond human understanding and cannot be interpreted through Christian terms. In previous novels, the writer, depicting the life paths of his characters, only tries to find the only right way to sanctity, and therefore to absolute freedom. In "Journal du voleur" one can already trace the writer's well-determined position: the way to absolute freedom-sanctity lies through renunciation of Christian tenets, betrayal as a manifestation of love, solitude, which is its logical consequence, a crime (preferably killing) and one's own death (a voluntary chosen death penalty as atonement).

However, if J. Genet in his early prose works outlined the way to sanctity of the closest people to God, sinners, then "Journal du voleur" is an expression of his own way, something different from the ideal, since the writer is a representative of both societies and cannot be completely dissolved in the environment of underclass. In this work the narrator already compares himself either to Jesus, or to God the Creator. Accordingly, he as a teenager associates himself with a Child of God, who, for God, is not only His beloved child, a subject of great care and concern, chosen and led by providence, though through terrible, exhausting hardships on the brink of desperation, but also the sole purpose of His efforts. Thus, by the intercession of God, he justifies his thievish way of life, because having committed a thievery, J. Genet shared the stolen with the same beggars as he was, that is, he committed moral acts, and therefore, the theft is under the protection of God, who takes pleasure in moral acts. Being unable to achieve sanctity through killing, he chooses his own, creative way, because "the work of art must be only a testimony to the sanctity" of the creator, since the heart has been put into its creation. So frankly and sincerely portraying the representatives of the marginalized world, the writer forces the reader to "confess evil in an innocent resemblance", and this can cost him honor and glory (as according to Yu. Kristeva: "Only after his death the writer of the execrable can possibly escape the fate of a freak, a scumbag or a disgusting one, and then he will be either forgotten or brought to the category of an unattainable model" ${ }^{57}$ ).

That is, the autobiographical character of J. Genet becomes a martyr, neglected and forgotten by moral society. He declares himself God, the Creator. As God sends His Son to take the burden of human sins, which means to feel the power and consequences of all sins, that is, to accept evil. He seeks to depict a resemblance of the noble myth of Creation and the Atonement on the pages of his novels.

${ }^{57}$ Кристева Ю. Отвращение // Силы ужаса: эссе об отвращении / [пер. с фр. А. Костикова]. Х.: Ф-Пресс, ХЦГИ, 2003. С. 52. 
Praising disgusting things with such affection, evoking aversion to him the writer approaches "the moment of the fall of the subject and object, the disgusting becomes tantamount to death. And the writing that allows to rise becomes equal to the resurrection. The writer then becomes confronted with the need to identify himself with Christ - whether or not to be, like Him, rejected and execrable" ${ }^{58}$.

\section{CONCLUSIONS}

By implementing his own ethic-and-aesthetic concept based on the Christian worldview, J. Genet simultaneously tries to bring the world of God into his marginal continuum. He sets out on a search of Evil in the way in which "ordinary" people search for Good. The interconnection of these pole concepts is the core of the writer's worldview. By demonstrating the "perversion" of religion, he provokes a shock in the reader as a guarantee of a rethinking of generally accepted norms and standards. Based on a key goal of the religious society - a sanctity, his character chooses the only possible way - through crime, and rapid fall that puts him outside the concepts of Good and Evil. J. Genet consciously or unconsciously sends the reader to divine duality, to coincidentia oppositirum, when God and Devil shared a divine origin, and the latter was an assistant, friend, and closest advisor of God. The world began to exist as a result of the break of initial unity, when the concepts of light and darkness, good and evil, were separated. However, in India, the ideal of the spirit is the jivanmukta, that is, "liberated in life", and, as M. Eliade explains it: "someone who, while living in the World, does not depend on the structure of the World" 59 . J. Genet's worldview rises above the opposites, returns to the idea that good and evil exist only in the "world of illusion" and in a transcendental perspective they are as visible and illusory as all other opposites.

In the most ancient religions, God is one and indivisible, he is neither a woman nor a man; he is an ideal being, even beyond gender. Trying to give the characters of his novels an aura of sanctity, J. Genet involuntarily transforms the myth about androgyny (according to M. Eliade, the Gnostic Christian sects made the ideas of androgyny central to their teachings). However, the realization of this myth in the writer's works is specific and manifests itself in transvestism. That is why the characters of his works which closest to God are always transvestites, men in the image of women. Sometimes it seems that the author-narrator deliberately confuses the reader, calling his characters either

${ }^{58}$ Кристева Ю. Отвращение // Силы ужаса : эссе об отвращении / [пер. с фр. А. Костикова]. Х.: Ф Пресс, ХЦГИ, 2003. Р. 62.

${ }^{59}$ Еліаде М. Священне і мирське; Міфи, сновидіння і містерії; Мефістофель і Андрогін; Окультизм, ворожбитство та культурні уподобання / [пер. Г. Кьоран, В. Сахно]. К.: Видавництво Соломії Павличко «Основи», 2001. С. 372. 
"he" or "she", but we regard it as conscious desire of J. Genet to blur the boundaries between female and male, to androgynization of the chosen one. An example of this is the Divine and Notre Dame from "Notre-Dame-DesFleurs". The person of the first one freely conjoins man and woman, some of her actions are truly masculine, others - a sincere manifestation of femininity. Notre-Dame-Criminal reveals his name to his friends only after wearing a woman's clothing for fun and gradually begins to act as a woman. This is where initiation of androgynization takes place, found in many ancient initiation rituals. It brings Notre-Dame closer to the realization of itself as a human being beyond gender, a man-woman, making her/him even closer to the true essence of God.

Since the way to sanctity for J. Genet lies through killing, then another problem of J. Genet's works, both prose and dramaturgical, is related to death, and more precisely the author's perception of it as a sacred mystery, which is only a stage of ancient initiation rituals.

\section{SUMMARY}

The problematic scope which J. Genet describes in his works (both prosaic, dramatic and poetic) are concentrated around the central problem of the writer's worldview - sanctity and finding a way to God. His Christian model of ideology has marginal origins. In his attempt to self-define and justify his existence in the marginal continuum, J. Genet transposes the sphere of the divine into the criminal world, thus he reverses the Christian religion. The gradual nature of the development of ethic-and-aesthetic concept of $\mathrm{J}$. Genet is analyzed on the background of a consistent comparison of the metaphorical system of his novels. If in the first prose works any representatives of a marginalized society are proclaimed divine, then in the latter works, the way to the identity with God (to absolute freedom) is complicated and extremely thorny, and is projected on a Christian model of worldview with its ultimate purpose - sanctity (for J. Genet the concept of sanctity and freedom are identical). Now, in order to deserve the right to be called God, a representative of the underclass must go all the way to complete self-denial (body and moral tortures, betrayal, solitude, killing and symbolic suicide). In accordance with their actions, on their way to sanctity the characters of the novels of the writer are called monks, saints, angels and archangels. 


\section{REFERENCES}

1. Bougon P. Politique, ironie et mythe dans Pompes funèbres // Europe. août-septembre 1996. N808-809. P. 66.

2. Genet J. Haute surveillance : (Nouvelle version). Paris : Gallimard, 1993. P. 50.

3. Genet J. Miracle de la rose // Oeuvres completes de Jean Genet. II. Paris, Gallimard, 1952. P. 160.

4. Genet J. Miracle de la rose // Oeuvres completes de Jean Genet. II. Paris, Gallimard, 1952. P. 239.

5. Genet J. Notre-Dame des Fleurs. Lyon: Barbezat-L'Arbalète, 1948. P. 139.

6. Genet J. Pompes Funèbres. Paris, Gallimard, 1953. P. 81.

7. Genet J. Querelle de Brest. Paris, Gallimard, 1953. P. 225.

8. Еліаде М. Священне і мирське; Міфи, сновидіння і містерії; Мефістофель і Андрогін; Окультизм, ворожбитство та культурні уподобання / [пер. Г. Кьоран, В. Сахно]. К.: Видавництво Соломії Павличко «Основи», 2001. С. 372.

9. Исаев С. Нежный // Строгий надзор / Жан Жене ; [Сост. С. Исаев]. М. : Изд-во «ГИТИС», 2000. С. 7-22.

10. Кристева Ю. Отвращение // Силы ужаса : эссе об отвращении / [пер. с фр. А. Костикова]. Х.: Ф Пресс, ХЦГИ, 2003. С. 52.

11. Покальчук Ю. Дзеркальні лабіринти «святого» Жене // Покоївки: [П’єса] / [пер. із фр. та післямова Ю. Покальчука]. Львів: Кальварія, 2002. С. 120.

\section{Information about the author: Semenets O. S.,}

$\mathrm{PhD}$ in Philological Sciences, Head of the Foreign Philology Department, Academic and Scientific Institute of Philology and Journalism,

V. I. Vernadskiy Taurida National University 33, John McCain str., Kyiv, 01042, Ukraine 